\title{
Reproductive performance of intensively managed primiparous gravid West African Dwarf goats fed pulverized bio-fibre waste-based diets

\author{
Ibhaze, G. A.
} \\ Department of Animal Production and Health, Federal University of Technology, Akure. Corresponding email: begladalways@yahoo.com; gaibhaze@futa.edu.ng \\ Tel: +2348055865289
}

\begin{abstract}
The feed intake and reproductive performance of intensively managed West African dwarf (WAD) gravid does were investigated. Twelve does weighing 11.90-13.05kg were used for the study. The does were fed on pulverized maize-cob based diets; maize-cob/cassava peel $(P M C / C s P)$, maize-cob/brewers' grain (PMC/BG), and maize-cob/cassava peel/brewers' grain $(P M C / C s P / B G)$. The does were allotted to the three dietary treatments such that four individually housed animals, each serving as a replicate and were also fed with concentrate diet at $1 \%$ of their body weight. Oestrus was synchronized in the does using $1 \mathrm{~mL} / 10 \mathrm{~kg}$ of Prostaglandin -Fa intramuscularly. Animals were mated with a proven buck. Dams were evaluated in a pregnancy trial while the kids born were evaluated in a pre-weaning growth trial. Dams were weighed at mating and forthnightly until kidding. Variables investigated were; feed intake, dam weight at mating, prior and after parturition, gestation length, weight gained during pregnancy, kid's birth and weaning weights, kid's daily weight gain, sex ratio. Feed intake revealed that does fed PMC/CsP recorded the highest total dry matter intake (TDMI) throughout the three trimesters $(727.16,832.85$ and $637.08 \mathrm{~g} /$ day) when compared to 339.38, 452.18 and 401.03g/day obtained for does fed PMC/BG. Weight gained was significantly $(P<0.05)$ higher in does on $P M C / C s P$. Mean birth weight, weaning weight and daily weight gain were higher for kids whose dams were fed PMC/CsP/BG. It can therefore be concluded that diets used in this study may serve as alternative feed for gravid goats while goats fed PMC/CsP/BG had better reproductive performance
\end{abstract}

Keywords: gravid, pulverized biofibre wastes, West African dwarf goats, intensive management, primiparous

\section{Introduction}

Adequate nutrition in terms of quality and quantity for gravid does is of great importance to sustain growth, development of foetus and enhanced performance of the animal and her offspring. However, in the tropics, inadequate nutrition is a great challenge contributing to production losses in ruminants, hence the use of bio-fibre waste which is non- conventional feed resources is gaining attention. Bio-fibre waste is a fibrous material considered to be valueless or environmental unfriendly derived from processing of wood, any agricultural farm produce (Ajayi, 2016).
Among such are cassava peels, maize-cobs and brewers' grain. Cassava peels are obtained during the processing of cassava tuber, are relatively low in protein. It contains appreciable amount of soluble carbohydrates and a high gross energy value of $3810 \mathrm{Kcal} / \mathrm{KgME}$ (Obioha, 1992) and is relished by goats. Maize-cobs are abundant during the harvesting period of maize but not normally consumed by ruminants due to their poor nutritive value compared with some other locally available crop residues and roughages(Ibrahim and Yashim, 2014). Brewer's grain is obtained during beer making process. It has been 
found to improve feed intake in ruminants when ensiled with low quality feed materials (Ibhaze, et al., 2014). The physiological state of an animal is one of the major determinants of the animal's feed intake. However, the quality of the feed must not be compromised, as pregnant animals need diets that can cater for their metabolic demands for the overall wellbeing of the animal and the foetus. This study was conducted to evaluate the feed intake and reproductive performance of West African dwarf does fed pulverized maize-cob based diets.

\section{Materials and method \\ Feed preparation}

Dried maize-cobs were collected from maize sellers and dried cassava peels (mixed varieties) were purchased from a market in Ibadan, Nigeria, while dried brewers' grain was purchased in a wet form from the brewery and sundried. These materials were manually mixed with other ingredients in the proportions specified in Table 1.

\section{Experimental measurements}

A total of twelve (12) primiparous West African dwarf does weighing 11.90$13.05 \mathrm{kgwere}$ purchased from a neighbouring village in Ibadan and allowed to acclamatize to the new environment for two weeks since they have been in the same ecological zone. The goats were tagged and randomly allotted to the three treatments such that four individually housed animals, each serving as a replicate were on each. They were offered fresh feed and water daily. The goats were synchronized using prostanglandin (PGF2 $\alpha$ ) at $1 \mathrm{~mL} / 10 \mathrm{~kg}$ intramuscularly to bring all the animals to oestrus and were then exposed to a proven buck for mating. Animals were offered concentrate feed at $1 \%$ of their body weight at $7.00 \mathrm{hrand}$ experimental diets were offered ad-libitum immediately after the consumption of the concentrate. Data collection commenced when animals did not return to oestrus. Parameters investigated were; feed intake, weight of doe at mating, prior to parturition, after parturition $(\mathrm{kg})$, gestation length, weight gain in pregnancy, kid birth weight, kid weaning weight, kid average daily weight gain (g/day), sex ratio, mortality at birth.

Experimental design and statistical analysis

The model adopted in this study was a oneway analysis of variance in a completely randomized design using the statistical analysis software (SAS, 2000) and means were separated using the Duncan Multiple Range Test of the same package.

\section{Results and Discussion}

The feed intake of gravid WAD goats fed pulverised maize-cob based diets is presented in Table 2. There were significant $(\mathrm{P}<0.05)$ differences in the total dry matter intake (TDMI) at the three trimesters with animals on diet $\mathrm{PMC} / \mathrm{CsP}$ having the highest values and those on diet PMC/BG with the least values. At early gestation, TDMI ranged from 339.38-727.16g/day, at mid pregnancy, values were 452.18$832.85 \mathrm{~g} /$ day while at late pregnancy, values ranged from 401.03-637.08g/day. The low intake observed in animals on $\mathrm{PMC} / \mathrm{BG}$ may be that animals found the diet unpalatable due to its form (dry) unlike when ensiled as reported by Ibhaze (2015). Ibeawuchi et al. (2002) opined that beyond nutritional composition, animals tend to consume more of palatable diets. Diar (1992) reported that ensiling improves acceptability, nutrient value of feed. Feed intake trend showed that at mid pregnancy, animals on all the treatment groups had increased TDMI. This observation could be due to the increased need for nutrients by 
the foetus for rapid growth and development at this stage. This corroborates the report of McDonald et al. (1995). David (2014) reported that energy requirement is affected by stage of production. The decrease in TDMI among goats at later stage of pregnancy is consistent with earlier reports (Akinsoyinu, 1985, Ogunwole, 2004). This decrease could be as a result of high levels of oestrogen in the blood that may alter metabolism and hence reduce energy requirements (Forbes, 1995), reduction in abdominal cavity as well as the space available for expansion of the rumen during feeding as the foetus increases in size (McDonald et al., 1995). The reproductive performance presented in Table 3 shows mean weights of does at mating which ranged from 11.90 to $13.05 \mathrm{~kg}$ with does on diet PMC/CsP having the highest weight of $13.05 \mathrm{~kg}$ and those on diet $\mathrm{PMC} / \mathrm{BG}$ had the least mean weight of $11.90 \mathrm{~kg}$. There were significant differences $(\mathrm{P}<0.05)$ observed between the weight of does at mating. Similarly, weight at parturition ranged from 14.08 to $17.25 \mathrm{~kg}$. The does on $\mathrm{PMC} / \mathrm{CsP}$ had a superior mean weight of $17.25 \mathrm{~kg}$ while those on $\mathrm{PMC} / \mathrm{BG}$ had the least mean weight of $14.08 \mathrm{~kg}$. As expected, all the animals on dietary treatments gained weight during the gestation period signifying that the feed intake and nutritional quality were adequate both for maintenance and production. However, mean weight gain during gestation was significantly $(\mathrm{P}<0.05)$ highest for animals on $\mathrm{PMC} / \mathrm{CsP}$ which could be attributed to higher feed intake and the twins born while the lowest for those on PMC/BG could be as a result of lower feed intake by the animals and their singleton birth. Values obtained are reflections of increase in doe's body weight due to pregnancy and not total weight gain. Similar observation was reported by Ososanya (2015) for West African dwarf ewe fed broiler litter. Orr and Treacher (1989) as cited by Ososanya (2015) reported that the level of concentrate feeding during pregnancy significantly affect all aspects of performance. Weight gain in pregnancy observed in this study is slightly lower than the values reported by Okunlola et al.(2015) for Red Sokoto goats fed Baobab fruit meal based diet. Despite the higher protein quality of $\mathrm{PMC} / \mathrm{BG}$, animals' least weight gain on this diet can be attributed to the least quantity of feed consumed by the animals. Although no significant $(\mathrm{P}>0.05)$ difference was observed in the kids' birth weight, higher value $(1.32 \mathrm{~kg})$ was obtained for kids of does fed $\mathrm{PMC} / \mathrm{CsP} / \mathrm{BG}$ and least $(1.15 \mathrm{~kg})$ for those on $\mathrm{PMC} / \mathrm{BG}$. This observation could have been influenced by the does' weight during pregnancy. This present results agree with the report of Peart (1967) as cited by Oderinwale et al. (2016) who opined that dam's weight during pregnancy influenced kid weight at birth. The birth weights were lower than $3.16-3.20 \mathrm{~kg}$ obtained for Kalahari goats by Oderinwale et al. (2016). This variation might be due to breed difference, mother's age and birth type (Ince, 2010). It may be pointed out that the least birth weight, weaning weight and daily weight gain of kids of does on $\mathrm{PMC} / \mathrm{BG}$ is a reflection of the lower feed intake by the animals. In this study, more males were produced than the females; however, the cause of this observation is difficult to be explained. 
Reproductive performance of intensively managed primiparous gravid West African Dwarf goats fed pulverized bio-fibre waste-based diets

Table 1: Ingredient and chemical composition (\%) of experimental diets

\begin{tabular}{llll}
\hline Ingredients & PMC/CsP & PMC/BG & PMC/CsP/BG \\
\hline Pulverised Maize- cob & 28.00 & 28.00 & 28.00 \\
Pulverised Cassava peels & 60.00 & - & 30.00 \\
Palm kernel cake & 10.00 & 10.00 & 10.00 \\
Brewers' grain & - & 60.50 & 30.00 \\
Urea & 1.00 & 0.50 & 1.00 \\
Dicalcium phosphate & 0.50 & 0.50 & 0.50 \\
Sulphur & 0.50 & 0.50 & 0.50 \\
Total & 100.00 & 100.00 & 100.00 \\
Chemical composition (\%) & & & \\
Dry matter & 90.90 & 90.57 & 90.06 \\
Crude protein & 14.66 & 21.18 & 18.62 \\
Crude fibre & 22.35 & 19.15 & 24.10 \\
Ether extract & 5.10 & 8.42 & 7.14 \\
Ash & 5.32 & 7.36 & 7.96 \\
Nitrogen free extract & 55.77 & 40.69 & 42.18 \\
Neutral detergent fibre & 51.14 & 40.01 & 41.11 \\
Acid detergent fibre & 32.15 & 30.10 & 31.13 \\
Acid detergent Lignin & 0.38 & 0.50 & 0.40 \\
Non-structural carbohydrate & 23.52 & 23.03 & 25.17 \\
Gross Energy (MJ/kgD) & 15.69 & 15.72 & 15.54 \\
\hline
\end{tabular}

PMC/CsP (pulveised maize -cob/Cassava peel), PMC/BG (pulverised maize-cob /brewers' grain),

$\mathrm{PMC} / \mathrm{CsP} / \mathrm{BG}$ (pulverized maize-cob /cassava peel/brewer's grain)

Table 2: Feed intake of gravid West African dwarf goats fed pulverized biofibre waste based diets

\begin{tabular}{|c|c|c|c|c|}
\hline Measurements & PMC/CsP & \multicolumn{2}{|l|}{ Diets } & \multirow[t]{2}{*}{ SEM } \\
\hline Early pregnancy & & & & \\
\hline Concentrate intake(g/day) & $120.05^{\mathrm{a}}$ & $110.14^{b}$ & $120.07^{\mathrm{a}}$ & 3.10 \\
\hline Test diet intake (g/day) & $607.11^{\mathrm{a}}$ & $229.24^{\mathrm{c}}$ & $306.05^{b}$ & 2.92 \\
\hline Total dry matter intake (g/day) & $727.16^{\mathrm{a}}$ & $339.38^{c}$ & $426.72^{b}$ & 5.14 \\
\hline Dry matter intake $(\% \mathrm{BW})$ & $3.85^{\mathrm{a}}$ & $2.53^{\mathrm{b}}$ & $3.39^{\mathrm{a}}$ & 0.16 \\
\hline Mid Pregnancy & & & & \\
\hline Concentrate intake(g/day) & $125.86^{\mathrm{b}}$ & $110.02^{\mathrm{c}}$ & $140.21^{\mathrm{a}}$ & 3.27 \\
\hline Test diet intake (g/day) & $706.99^{a}$ & $342.10^{\mathrm{c}}$ & $585.11^{\mathrm{b}}$ & 6.64 \\
\hline Total dry matter intake (g/day) & $832.85^{\mathrm{a}}$ & $452.18^{\mathrm{c}}$ & $725.32^{b}$ & 7.59 \\
\hline Dry matter intake $(\% \mathrm{BW})$ & $4.74^{\mathrm{a}}$ & $3.11^{\mathrm{b}}$ & $4.18^{\mathrm{a}}$ & 0.19 \\
\hline Late Pregnancy & & & & \\
\hline Concentrate intake (g/day) & $150.07^{\mathrm{a}}$ & $135.05^{\mathrm{b}}$ & $155.02^{\mathrm{a}}$ & 2.88 \\
\hline Test diet intake(g/day) & $487.01^{\mathrm{a}}$ & $265.98^{\mathrm{b}}$ & $408.43^{\mathrm{a}}$ & 3.88 \\
\hline Total dry matter intake (g/day) & $637.08^{\mathrm{a}}$ & $401.03^{c}$ & $563.45^{\mathrm{b}}$ & 4.85 \\
\hline Dry matter intake (\% BW) & $4.25^{\mathrm{a}}$ & $3.23^{\mathrm{b}}$ & $3.64^{\mathrm{b}}$ & 0.05 \\
\hline
\end{tabular}

abc: Means along the same row with identical superscripts are not significantly $(\mathrm{P}>0.05)$ different

Table 3: Reproductive performance of West African Dwarf goats fed pulverized biofibre wastes based diets

\begin{tabular}{|c|c|c|c|c|}
\hline \multirow[b]{2}{*}{ Parameters } & \multicolumn{2}{|l|}{ Diets } & \multirow[b]{2}{*}{ SEM } & \\
\hline & PMC/CsPPMC/ BG & $\mathrm{PMC} / \mathrm{CsP} / \mathrm{BG}$ & & \\
\hline Mean wt of does at mating $(\mathrm{kg})$ & $13.05^{\mathrm{ab}}$ & $11.90^{\mathrm{bc}}$ & $12.48^{\mathrm{b}}$ & 1.35 \\
\hline Mean wt at parturition $(\mathrm{kg})$ & $17.25^{\mathrm{a}}$ & $14.08^{\mathrm{bc}}$ & $15.79^{\mathrm{b}}$ & 1.05 \\
\hline Mean wt after parturition & $15.67^{\mathrm{a}}$ & $13.03^{\mathrm{b}}$ & $13.94^{\mathrm{b}}$ & 1.24 \\
\hline Mean gestation length (days) & $147.50^{\mathrm{ab}}$ & $150.01^{\mathrm{a}}$ & $140.50^{c}$ & 6.02 \\
\hline Mean wt gain in pregnancy $(\mathrm{kg})$ & $4.20^{\mathrm{a}}$ & $2.18^{\mathrm{bc}}$ & $3.31^{\mathrm{b}}$ & 0.32 \\
\hline Mean birth wt of kids $(\mathrm{kg})$ & 1.25 & 1.15 & 1.32 & 0.07 \\
\hline Mean wt of kids at weaning $(\mathrm{kg})$ & $3.82^{\mathrm{b}}$ & $2.75^{\mathrm{c}}$ & $4.50^{\mathrm{a}}$ & 0.13 \\
\hline Mean daily wt gain of kids from $0-12$ weeks $\left(\right.$ gday $\left.^{-1}\right)$ & $28.55^{\mathrm{b}}$ & $17.77 \mathrm{c}$ & $35.33^{\mathrm{a}}$ & 1.20 \\
\hline Kid mortality at birth & 0 & 0 & 0 & - \\
\hline Mean sex ratio of M:F (\%) & $75: 25$ & $50: 50$ & $67: 34$ & - \\
\hline
\end{tabular}

Means on the same row with same superscript are not statistically different $(P>0.05)$ 


\section{Conclusion}

This study has indicated that goats can be managed intensively without loss of animals, abortion or miscarriages if given adequate attention because during this study, no mortality was recorded. Dams fed $\mathrm{PMC} / \mathrm{CsP} / \mathrm{BG}$ had better reproductive performance in terms of birth weight, weaning weight and daily weight gain of kids. The use of the test ingredients in the diets of goats is a farmer friendly means of mitigating the adverse effects of dry season on both the animals and the livestock farmers in Nigeria

\section{References}

Ajayi, B. 2016. Adding value to biofibre wastes: A lesson from creation. Inaugural Lecture series 77 of The Federal University of Technology, Akure, Ondo State. Pp 8-9.

Akinsoyinu, A. O. 1985. Nutrient requirements of sheep and goats in Nigeria. Small Ruminant Production in Nigeria. Proc. National Conference on Small Ruminant Production , NAPRI, Zaria, Pp 12-17

David, G. P. 2014. Nutritional requirements of goats. The Merck Veterinary Manual.

Diar, H. A. 1992. Traditional fermentation technology and food policy in Africa. Appropriate Tech. 19 (3): 21-23

Forbes, J. M. 1995. Voluntary food intake and diet selection in farm animals. $\mathrm{CAB}$ International, Wallingford, UK, pp 539

Ibeawuchi, J. A. Ahamefule, F. O. and Oche, J. E. 2002. An assessment of the nutritive value of the browse plants in Markurdi. Nigerian Agricultural Journal. 33:128-135
Ibhaze, G. A., Babayemi, O. J. and Olorunnisomo, O. A. 2014. Acceptability and digestibility of ensiled mixtures of corncob, cassava peels and brewers' grain by West African Dwarf goats. Nigerian Journal of Animal Production 41(2): 139-145.

Ibhaze, G. A. 2015. Feeding quality of fermented maize-cob based diets as feed for West African Dwarf goats. Applied Tropical Agriculture 20 (1) Pp 52-56

Ibrahim, T. A. and Yashim, S. M. 2014. Growth response, nutrient digestibility and haematological Parameters of Red Sokoto Bucks Fed lime treated maize-cob supplemented with concentrate diet. Nigerian Journal of Animal Science, 16(2): 264-271

Ince, D. 2010. Reproduction performance of Saanen goats raised under extensive conditions. African Journal of Biology 9: 8253-8256

Mcdonald, P., Edwards, R. A, Greenhalgh, J. F. D, Morgan, C. A. 1995. Animal Nutrition . Fifth Edition. Longman Scientific and Technical, Longman Group UK, Ltd. Pp 429

Obioha, F. C. 1992. Poultry production in the tropics. Acena publishers, Enugu, Nigeria. Pp2-50

Oderinwale, O. A., Oluwatosin, B. O., Sowande, O. S. and Bemji, M. N. 2016. Effects of concentrate diets supplementation on some pregnancy variables and weight of kids of Kalahari Red does drazed on Chloris gayana. Proceedings of the Nigerian Society for Animal production 20-24 March, held at Federal University of Agriculture Abeokuta, Ogun State. Pp 572-576. 
Reproductive performance of intensively managed primiparous gravid West African Dwarf goats fed pulverized bio-fibre waste-based diets

Ogunwole, O. A. 2004. Evaluation of rumen epithelial scrapings of cattle for pregnant, lactating and preweaned lambs of West African dwarf sheep. Ph.D thesis. University of Ibadan Pp 282

Okunlola, D. O. Olorunnisomo, O. A., Amuda, A. J., Agboola, A. S. and Ojoawo, O. T. 2015. Reproductive performance of Red sokoto goats fed baobab (Adansonia digitata L.) fruit meal based diet. Proceeding of the $20^{\text {th }}$ Annual Conference of Animal Science Association of Nigeria held at the International Conference centre of the University of Ibadan, 610 September Pp 159-162

Orr, R. J and Treacher, T. T. 1989. The effect of concentrate level on the intake of grass silages by ewes in late pregnancy. Anim. Prod., 48:109-120
Ososanya, T. O. 2016. Effect of broiler litter supplementation on reproductive performance of West African Dwarf sheep. Nigerian Journal of Animal Production. 42(2) :180-186.

Peart, J. N. 1967. The effect of different levels of nutrition during late pregnancy on the subsequent milk production of Blackface ewes and on the growth of their lambs. Journal of Agricultural Sciences (Camb.). 68, 365-371

SAS, 2000. Statistical Analysis System. SAS User's Guide Statistics Institute Inc. Version 8. North carolina USA.

Received: $24^{\text {th }}$ September, 2016 Accepted: $28^{\text {th }}$ January, 2017 